\title{
PENETAPAN STATUS PENGGUNAAN BARANG MILIK NEGARA DALAM RANGKA OPTIMALISASI PENERIMAAN NEGARA
}

\author{
Determination of Status Use of State Property in the State Revenue \\ Optimize
}

\author{
Hamdi \\ Direktorat Jenderal Kekayaan Negara \\ email: hamdie@gmail.com
}

\begin{abstract}
SOA Usage Status Determination Regulation in line with those mandated by Government Regulation Number 27 of 2014 on Management of State and Regional Assets has been regulated in Minister of Finance Regulation Number 246/PMK.06/2014 on Procedures for the Implementation of State Assets Utilization and Minister of Finance Regulation Number 41/PMK.06/2015 on Delegation of Certain Authority and Responsibility From State Assets Manager To State Assets User. The implementation of SOA Usage Status Determination in Regional Office Directorate General of State Assets Lampung Province and Bengkulu Province is not yet optimal because a little number of SOA status been defined. SOA optimization through utilization in order to gain state's revenue through non-tax revenue is not the main goal, but the optimal use of SOA in order to support the implementation of the tasks and functions of Ministry/Agency. The implementation of State Asset Management Information System application was expected to support SOA management, especially related to supervision and control in the implementation of SOA Usage Status Determination.
\end{abstract}

Keywords: State-Owned Assets, Usage Status Determination, SOA Utilization.

\section{abstrak}

Peraturan SOA Status Penggunaan Penentuan sejalan dengan yang diamanatkan oleh Peraturan Pemerintah Nomor 272014 tentang Pengelolaan Barang Milik Negara dan Daerah telah diatur dalam Peraturan Menteri Keuangan Nomor 246/PMK.06/2014 tentang Tata Cara Pelaksanaan Penggunaan Barang Milik Negara dan Peraturan Menteri Keuangan Nomor 41/PMK.06/2015 tentang Pendelegasian Kewenangan dan Tanggung Jawab Tertentu dari Pengelola Barang Kkpada Pengguna Barang. Implementasi SOA Status Penggunaan Penentuan di Kanwil DJKN Provinsi Lampung dan 
Provinsi Bengkulu belum optimal karena sejumlah kecil status SOA telah ditetapkan. SOA optimasi melalui pemanfaatan untuk mendapatkan penerimaan negara melalui penerimaan negara bukan pajak bukanlah tujuan utama, tetapi penggunaan optimal dari SOA dalam rangka mendukung pelaksanaan tugas dan fungsi Kementerian/Lembaga. Penerapan aplikasi Sistem Informasi Negara Asset Management diharapkan untuk mendukung manajemen SOA, terutama terkait dengan pengawasan dan pengendalian dalam pelaksanaan SOA Status Penggunaan Penentuan.

Kata Kunci: Aset Milik Negara, Penggunaan Status Penetapan, SOA Pemanfaatan

\section{A. Pendahuluan}

Tahun 2006 merupakan babak baru dalam sejarah pengelolaan kekayaan Negara Republik Indonesia pada umumnya dan pengelolaan Barang Milik Negara (BMN) pada khususnya, karena pada Tahun 2006 tersebut terbit Peraturan Pemerintah Nomor 6 Tahun 2006 tentang Pengelolaan Barang Milik Negara/Daerah sebagai kelanjutan dari 3 (tiga) paket undang-undang yang telah lahir sebelumnya, yaitu Undang-Undang Nomor 17 Tahun 2003 tentang Keuangan Negara, Undang-Undang Nomor 1 Tahun 2004 tentang Perbendaharaan Negara dan Undang-Undang Nomor 15 Tahun 2004 tentang Pemeriksaan Pengelolaan dan Tanggung Jawab Keuangan Negara, telah dibentuk pula satu unit organisasi setingkat eselon I di lingkungan Kementerian Keuangan yang memunyai tugas dan fungsi melakukan pengelolaan kekayaan Negara yakni Direktorat Jenderal Kekayaan Negara (DJKN). ${ }^{1}$

Paradigma baru pengelolaan kekayaan Negara yang ditandai dengan reformasi hukum di bidang pengelolaan kekayaan Negara, yaitu dengan terbitnya Peraturan Pemerintah Nomor 6 Tahun 2006 tentang Pengelolaan Barang Milik Negara/Daerah sebagaimana diubah dengan Peraturan Pemerintah Nomor 38 Tahun 2008 tentang Perubahan Atas Peraturan Pemerintah Nomor 6 Tahun 2006 tentang Pengelolaan Barang Milik Negara/Daerah, menjadikan berubahnya peran Direktorat Jenderal Kekayaan Negara dari aset administrator menjadi asset manager. ${ }^{2}$ Peraturan Pemerintah Nomor 6 Tahun 2006 tentang Pengelolaan Barang Milik Negara/Daerah sebagaimana diubah dengan Peraturan Pemerintah Nomor 38 Tahun 2008 tentang Perubahan Atas Peraturan Pemerintah Nomor 6 Tahun 2006 tentang Pengelolaan Barang Milik Negara/Daerah, dianggap sudah

\footnotetext{
${ }^{1}$ Media Kekayan Negara, Roadmap Strategic Assets Management, Edisi No. 09 Tahun III/2012, hlm. 16.

${ }^{2}$ Annual Report Direktorat Jenderal Kekayaan Negara Tahun 2013, hlm. 146.
} 
tidak sesuai dengan perkembangan pengelolaan Barang Milik Negara/Daerah, maka pada Tahun 2014 diterbitkanlah Peraturan Pemerintah Nomor 27 Tahun 2014 tentang Pengelolaan Barang Milik Negara/Daerah dan berlaku sejak ditetapkan tanggal 24 April 2014.

Latar belakang dari penyempurnaan Peraturan Pemerintah Nomor 6 Tahun 2006 antara lain karena adanya dinamika pengelolaan Barang Milik Negara/Daerah terkait dengan sewa, kerjasama pemanfaatan dan BMN luar negeri yang harus diperlakukan secara khusus. Selain itu adanya multitafsir terhadap ketentuan dalam PP Nomor 6 Tahun 2006 terkait Badan Layanan Umum (BLU), Penerimaan Negara Bukan Pajak (PNBP), dan kasus-kasus yang muncul dalam pengelolaan Barang Milik Negara/Daerah serta adanya temuan pemeriksaan BPK yang menuntut pemerintah untuk menyempurnakan Peraturan Pemerintah Nomor 6 Tahun 2006. ${ }^{3}$

Prinsip umum penggunaan BMN adalah bahwa penggunaan Barang Milik Negara dibatasi hanya untuk penyelenggaraan tugas dan fungsi Kementerian/Lembaga dan Pengguna Barang wajib menyerahkan Barang Milik Negara berupa tanah dan/atau bangunan yang tidak digunakan dalam penyelenggaraan tugas dan fungsinya kepada Pengelola Barang.

Salah satu tujuan dalam Penetapan Status Penggunaan Barang Milik Negara pada Kementerian/Lembaga adalah dalam rangka akuntabilitas pengelolaan pengelolaan Barang Milik Negara dengan tetap menjunjung tinggi tata kelola pemerintahan yang baik (Good Governance), dan kepastian hak, wewenang serta tanggung jawab Menteri/Pimpinan Lembaga sebagai Pengguna Barang dalam melaksanakan penyelenggaraan tugas dan fungsinya. Sehingga dengan demikian penggunaan Barang Milik Negara tidak boleh di luar tugas dan fungsinya. Penetapan status penggunaan mutlak harus dilaksanakan karena merupakan salah satu proses awal pengelolaan sebelum dilakukan pengelolaan lainnya seperti pemanfaatan, pemindahtanganan, dan penghapusan.

Pada saat ini, optimalisasi penerimaan negara melalui pemanfaatan BMN belum menjadi perhatian utama Kementerian/Lembaga. Hal ini tidak terlepas dari belum adanya kesadaran (Awareness) dari para pengurus BMN di tingkat Kementertian/Lembaga untuk melakukan penataan Barang Milik Negara melalui ketentuan yang benar karena kurangnya pemahaman terhadap ketentuan yang berlaku. Kontras dengan hal tersebut, adanya pemanfaatan justru dapat menjadi masalah bagi Kementerian/Lembaga yang telah melakukan pemanfaatan Barang Milik Negara tanpa persetujuan Menteri Keuangan, karena dinilai tidak memberikan kontribusi yang maksimal bagi negara serta tidak adanya kepatuhan (compliance) terhadap

\footnotetext{
${ }^{3}$ Media Kekayaan Negara, Public-Private Partnership, Edisi No. 17 Tahun V/2014
} 
peraturan perundang-undangan yang ada di bidang pengelolaan Barang Milik Negara.

Berdasarkan latar belakang di atas, maka permasalahan yang ingin penulis kaji adalah tentang regulasi Penetapan Status Penggunaan Barang Milik Negara dalam peraturan perundang-undangan yang berlaku, dan pelaksanaan Penetapan Status Penggunaan Barang Milik Negara dalam rangka optimalisasi penerimaan negara di Kantor Wilayah DJKN Provinsi Lampung dan Provinsi Bengkulu.

Metode penelitian yang digunakan dalam penulisan ini adalah metode penelitian normatif empiris dengan pendekatan kualitatif. Metode penelitian normatif empiris menggunakan data sekunder dan dilakukan dengan penelitian kepustakaan (library research). Untuk melengkapi data yang dibutuhkan dalam penelitian, dilakukan wawancara "Intervieuw" yaitu cara untuk memperoleh data dan informasi dilakukan dengan berkomunikasi langsung dengan pihak-pihak yang terkait dengan objek penelitian dan pengamatan "Observation" yang ada kaitannya dengan penelitian ini. Pendekatan masalah dalam penelitian ini adalah yuridis empiris dengan studi langsung ke lapangan dalam hal ini Kantor Wilayah Direktorat Jenderal Kekayaan Negara (DJKN) Provinsi Lampung dan Provinsi Bengkulu dalam pelaksanaan pengelolaan Barang Milik Negara.

\section{B. Pembahasan}

\section{Regulasi Penetapan Status Penggunaan Barang Milik Negara Dalam Peraturan Perundang-undangan yang Berlaku}

Terkait pengelolaan Barang Milik Negara, Undang-Undang Nomor 1 Tahun 2004 menyebutkan:

a. Menteri Keuangan mengatur pengelolaan Barang Milik Negara (Pasal 42 ayat (1)).

b. Menteri/Pimpinan Lembaga adalah Pengguna Barang bagi Kementerian Negara/ Lembaga yang dipimpinnya (Pasal 42 ayat (2)).

c. Kepala Kantor dalam lingkungan Kementerian/Lembaga adalah Kuasa Pengguna Barang dalam lingkungan kantor yang bersangkutan (Pasal 42 ayat (3)).

d. pengguna Barang dan/Kuasa Pengguna Barang wajib mengelola dan menatausahakan Barang Milik Negara yang berada dalam penguasaannya dengan sebaik-baiknya (Pasal 44).

e. Barang Milik Negara yang berupa tanah yang dikuasai oleh Pemerintah Pusat harus disertifikatkan atas nama Pemerintah RI (Pasal 49 ayat (1)).

f. Bangunan Milik Negara harus dilengkapi dengan bukti status kepemilikan dan ditatausahakan secara tertib (Pasal 49 ayat (2)).

g. Tanah dan Bangunan Milik Negara yang tidak digunakan untuk kepentingan penyelenggaraan tugas pokok dan fungsi Instansi yang 
bersangkutan, wajib diserahkan pemanfaatannya kepada Menteri Keuangan untuk kepentingan penyelenggaraan Tugas Pemerintahan Negara (Pasal 49 ayat (3)).

h. Barang Milik Negara dilarang untuk diserahkan kepada pihak lain sebagai pembayaran atas tagihan kepada Pemerintah Pusat (Pasal 49 ayat (4)).

i. Barang Milik Negara dilarang digadaikan atau dijadikan jaminan untuk mendapatkan pinjaman (Pasal 49 ayat (5)).

j. ketentuan mengenai pedoman teknis dan administrasi pengelolaan Barang Milik Negara diatur dengan Peraturan Pemerintah (Pasal 49).

Pelaksanaan ketentuan tersebut telah ditetapkan Peraturan Pemerintah Nomor 27 Tahun 2014 tentang Pengelolaan Barang Milik Negara/Daerah yang merupakan Pengganti dari Peraturan Pemerintah Nomor 6 Tahun 2006 sebagaimana telah diubah dengan Peraturan Pemerintah Nomor 38 Tahun 2008 tentang Perubahan Peraturan Pemerintah Nomor 6 Tahun 2006 tentang Pengelolaan Barang Milik Negara/Daerah, karena sudah tidak sesuai dengan perkembangan pengelolaan Barang Milik Negara. Objek Penggunaan Barang Milik Negara secara umum adalah semua barang yang dibeli atau diperoleh atas beban Anggaran Pendapatan dan Belanja Negara atau barang yang berasal dari perolehan lainnya yang sah. Dalam Pelaksanaannya Barang Milik Negara dibagi menjadi 2(dua) garis besar yaitu:

a. Barang Milik Negara berupa tanah dan/atau bangunan; dan

b. Barang Milik Negara berupa selain tanah dan/atau bangunan

Pembagian tersebut sebagaimana yang tercantum dalam UndangUndang Nomor 1 Tahun 2004 tentang Perbendaharaan Negara. Sedangkan Subjek Penggunaan Barang Milik Negara adalah pihak-pihak yang terlibat dalam pelaksanaan penggunaan Barang Milik Negara yaitu Pengelola Barang dan Pengguna Barang/Kuasa Pengguna Barang. Penggunaan Barang Milik Negara merupakan inti dari keseluruhan siklus pengelolaan Barang Milik Negara. Barang Milik Negara diadakan oleh Kementerian/Lembaga untuk digunakan dalam rangka melaksanakan tugas dan fungsi mereka. Penggunaan Barang Milik Negara ini tentunya terlebih dahulu sudah direncanakan dan dipertimbangkan secara matang, sehingga optimalisasi atas Barang Milik Negara terpenuhi.

Proses Penggunaan dalam rangkaian pengelolaan Barang Milik Negara merupakan proses yang dilaksanakan setelah tahap pengadaan. Tahap pengadaan terjadi apabila suatu instansi pemerintah telah melakukan perencanaan kebutuhan atas Barang Milik Negara disertai dengan penganggarannya. Proses perencanaan menjadi kunci dari tahap penggunaan Barang Milik Negara, karena efisiensi dan optimalisasi Barang Milik Negara atas pengadaan Barang yang akan dilaksanakan harus sesuai dengan peruntukan atau tugas dan fungsi instansi yang bersangkutan, sehingga 
apabila terdapat barang yang tidak digunakan sesuai dengan tugas dan fungsi Kementerian/Lembaga yang bersangkutan maka pengelolaan Barang Milik Negara tersebut harus diserahkan kepada Pengelola Barang sebagai Barang Milik Negara Idle (BMN Idle), yang selanjutnya oleh Pengelola Barang BMN Idle tersebut akan dioptimalkan penggunaannya antara lain dengan cara diberikan kepada Kementerian/Lembaga lain yang membutuhkan. Pengelolaan Barang Milik Negara pada prinsipnya memiliki tujuan untuk mencapai kondisi yang ideal dalam optimalisasi penggunaan aset, kondisi ideal ini mencakup seluruh aspek mulai dari perencanaan, pengadaan, penggunaan sampai pada proses penghapusan. Khusus pada tahap penggunaan Barang Milik Negara, kondisi yang ideal akan dicapai jika Barang Milik Negara yang telah diadakan benar-benar digunakan secara maksimal untuk melaksanakan tugas dan fungsi dari Kementerian/Lembaga bersangkutan.

Tahap penggunaan Barang Milik Negara ditandai dengan adanya Penetapan Status Penggunaan yang merupakan gerbang penting dalam kegiatan/proses selanjutnya terkait pengelolaan maupun penatausahaan Barang Milik Negara. Konsekuensi dari adanya Penetapan Status Penggunaan Barang Milik Negara adalah bahwa ketika suatu barang ditetapkan sebagai Barang Milik Negara dengan terbitnya Surat Keputusan Status Penggunaan, maka Pengguna Barang mendapatkan penguasaan dalam menggunakan Barang Milik Negara dimaksud untuk menyelenggarakan tugas dan fungsinya sebagai instansi pemerintah. Selain itu, biaya operasional dan pemeliharaan Barang Milik Negara juga bisa diusulkan untuk disediakan dalam Anggaran Pendapatan Belanja Negara. Dengan adanya penetapan status tersebut maka Pengguna Barang/Kuasa Pengguna Barang berkewajiban mengelola serta menatausahakan Barang Milik Negara yang ada pada penguasaannya. Terkait kewenangan dalam menetapkan status penggunaan Barang Milik Negara, Pasal 14 Peraturan Pemerintah Nomor 27 Tahun 2014 menyatakan bahwa Status penggunaan Barang Milik Negara ditetapkan oleh Pengelola Barang. Selanjutnya dalam Pasal 16 dinyatakan bahwa Pengelola Barang dapat mendelegasikan penetapan status penggunaan atas Barang Milik Negara selain tanah dan/atau bangunan dengan kondisi tertentu kepada Pengguna Barang/Kuasa Pengguna Barang.

Menindaklanjuti Peraturan Pemerintah Nomor 27 Tahun 2014, khususnya terkait Penetapan Status Penggunaan BMN telah ditetapkan Peraturan Menteri Keuangan Nomor 246/PMK.06/2014 tentang Tata Cara Pelaksanaan Penggunaan Barang Milik Negara dan Peraturan Menteri Keuangan Nomor 4/PMK.06/2015 tentang Pendelegasian Kewenangan dan Tanggung Jawab Tertentu Dari Pengelola Barang Kepada Pengguna Barang. Peraturan Menteri Keuangan Nomor 246/PMK.06/2014, mengatur tata cara pelaksanaan penggunaan Barang Milik Negara yang berada pada Pengelola 
Barang dan Pengguna Barang/Kuasa Pengguna Barang. Pasal 2 ayat (2) menyatakan Pengaturan tata cara penggunaan BMN tersebut meliputi:

a. penetapan status penggunaan Barang Milik Negara;

b. penetapan status penggunaan Barang Milik Negara untuk dioperasikan oleh pihak lain;

c. penggunaan sementara Barang Milik Negara; dan

d. pengalihan status penggunaan Barang Milik Negara

Selanjutnya Pasal 6 ayat (1) mengatur bahwa Menteri Keuangan selaku Pengelola Barang memiliki kewenangan dan tanggung jawab:

a. menetapkan status penggunaan Barang Milik Negara;

b. menetapkan status penggunaan Barang Milik Negara untuk dioperasikan oleh pihak lain;

c. memberikan persetujuan penggunaan sementara Barang Milik Negara;

d. memberikan persetujuan alih status penggunaan Barang Milik Negara; dan melakukan pengawasan dan pengendalian terhadap pelaksanaan penggunaan Barang Milik Negara

Kewenangan Menteri Keuangan dalam menetapkan status penggunaan BMN diatur dalam Pasal 6 ayat (2), yaitu meliputi:

a. Barang Milik Negara berupa tanah dan/atau bangunan;

b. Barang Milik Negara selain tanah dan/atau bangunan:

1) yang memiliki bukti kepemilikan, seperti sepeda motor, mobil, kapal, dan pesawat terbang;

2) yang tidak memiliki bukti kepemilikan dengan nilai perolehan di atas Rp100.000.000,00 (seratus juta rupiah) per unit/satuan;

c. Barang Milik Negara yang dari awal pengadaannya direncanakan untuk dilakukan pemindahtanganan berupa Penyertaan Modal Pemerintah Pusat (PMPP), kecuali ditetapkan lain oleh Peraturan Perundang-undangan.

Kewenangan dan tanggung jawab Menteri Keuangan menetapkan status penggunaan $\mathrm{BMN}$ tersebut sudah sesuai dengan amanat ketentuan yang lebih tinggi. Pembatasan BMN berupa selain tanah dan/atau bangunan yang memiliki bukti kepemilikan dan yang tidak punya bukti kepemilikan dengan nilai perolehan di atas Rp100.000.000,00 per unit/satuan dimaksudkan agar Menteri Keuangan selaku Pengelola Barang lebih fokus dalam pengawasan dan pengendalian penggunaan BMN yang memunyai nilai besar. Lebih lanjut, BMN yang memiliki bukti kepemilikan artinya adalah kepemilikan terhadap barang tersebut dilengkapi bukti kepemilikan yang dikeluarkan oleh instansi yang berwenang, sebagai contoh kendaraan roda dua dan kendaraan roda empat dilengkapi Bukti Kepemilikan Kendaraan Bermotor (BPKB) yang dikeluarkan oleh Kepolisian, sedangkan kapal dan pesawat terbang bukti kepemilikan dikeluarkan oleh Kementerian Perhubungan. 
Sedangkan BMN yang tidak memiliki bukti kepemilikan artinya adalah kepemilikan barang tersebut tidak memerlukan adanya suatu bukti kepemilikan yang dikeluarkan instansi yang berwenang, sebagai contoh barang-barang inventaris seperti meja kursi, peralatan komputer, mesin genset dan lain-lain. Kepemilikan barang tersebut cukup dibuktikan dengan faktur pembelian dan berita acara serah terima barang. Apabila nilai perolehan barang tersebut di atas Rp100.000.000,00 per unit/satuan, maka kewenangan menetapkan status penggunaannya ada pada Menteri Keuangan. BMN selain tanah dan/atau bangunan yang tidak punya bukti kepemilikan dan nilainya dibawah Rp100.000.000,00 per unit/satuan jumlahnya sangat banyak dan tersebar di Kementerian/Lembaga, maka akan lebih efektif apabila kewenangan menetapkan status penggunaannya ada di pengguna Barang. Oleh karena itu pengaturan kewenangan dan tanggung jawab dalam menetapkan status penggunaan, menurut hemat penulis telah mempertimbangkan efektifitas dan efisiensi dalam pelaksanaannya.

Selanjutnya BMN yang dari awal pengadaannya direncanakan untuk dilakukan pemindahtanganan berupa PMPP artinya bahwa sesuai dokumen penganggaran BMN tersebut diperuntukkan bagi Badan Usaha Milik Negara (BUMN) atau Badan Hukum lainnya yang dimiliki Negara dalam rangka penugasan pemerintah dengan pertimbangan Barang Milik Negara tersebut akan lebih optimal apabila dikelola oleh BUMN atau Badan Hukum lainnya yang dimiliki Negara, baik yang sudah ada maupun yang akan dibentuk. PMPP adalah pengalihan kepemilikan BMN yang semula merupakan kekayaan negara yang tidak dipisahkan menjadi kekayaan negara yang dipisahkan untuk diperhitungkan sebagai modal/saham negara pada BUMN, atau Badan Hukum lainnya yang dimiliki Negara dalam rangka pendirian, pengembangan, dan peningkatan kinerja BUMN atau Badan Hukum lainnya yang dimiliki Negara.

Pasal 6 ayat (3) mengatur bahwa kewenangan dan tanggung jawab Menteri Keuangan secara fungsional dilaksanakan oleh Direktur Jenderal Kekayaan Negara dan Pasal 6 ayat (4) mengatur bahwa Direktur Jenderal Kekayaan Negara dapat menunjuk pejabat struktural di lingkungan Direktorat Jenderal Kekayaan Negara untuk melaksanakan sebagian kewenangan dan tanggung jawab tersebut. Kewenangan dan tanggung jawab Menteri/Pimpinan Lembaga selaku Pengguna Barang diatur dalam Pasal 7 ayat (1), yaitu:

a. menetapkan status penggunaan Barang Milik Negara yang berada dalam penguasaannya;

b. mengajukan permohonan penetapan status penggunaan Barang Milik Negara kepada Pengelola Barang, termasuk penetapan status penggunaan Barang Milik Negara untuk dioperasikan kepada pihak lain; 
c. mengajukan permohonan persetujuan penggunaan sementara Barang Milik Negara kepada Pengelola Barang; dan

d. melakukan pengawasan dan dan pengendalian atas penggunaan Barang Milik Negara yang berada dalam penguasaannya.

Pasal 7 ayat (2) mengatur bahwa kewenangan Menteri/Pimpinan Lembaga dalam menetapkan status penggunaan Barang Milik Negara meliputi:

a. Barang Milik Negara selain tanah dan/atau bangunan, yang tidak memiliki bukti kepemilikan, dengan nilai perolehan sampai dengan Rp100.000.000,00 (seratus juta rupiah) per unit/satuan; dan

b. alat utama sistem persenjataan;

Subtansi pengaturan kewenangan dan tanggung jawab menetapkan status penggunaan $\mathrm{BMN}$ selain tanah dan/atau bangunan yang tidak punya bukti kepemilikan dengan nilai perolehan sampai dengan Rp100.000.000,00 kepada Menteri/Pimpinan Lembaga selaku Pengguna Barang, menurut hemat penulis sudah tepat dan telah sesuai dengan tujuan pengaturannya yaitu dalam rangka efektifitas dalam pelaksanaannya. Sedangkan tujuan pengaturan terhadap BMN berupa alat utama sistem persenjataan dalam rangka menjaga kerahasian dalam rangka pertahanan negara. Oleh karena itu Kementerian Pertahanan selaku Pengguna Barang dari BMN berupa alat utama sistem persenjataan diberikan kewenangan untuk menetapkan status penggunaannya. Pasal 7 ayat (3) mengatur kewenangan dan tanggung jawab Menteri/Pimpinan Lembaga selaku Pengguna Barang secara fungsional dilaksanakan oleh pejabat struktural di lingkungan unit organisasi eselon I yang membidangi pengelolaan Barang Milik Negara pada Kementerian/Lembaga. Dalam Pasal 7 ayat (4) menyatakan bahwa Menteri/Pimpinan Lembaga selaku Pengguna Barang dapat menunjuk pejabat di lingkungan kantor pusat dan/atau pejabat di lingkungan instansi vertikal untuk melaksanakan kewenangan dan tanggung jawab tersebut dan dalam Pasal 7 ayat (5) menyatakan ketentuan mengenai kewenangan dan tanggung jawab Pengguna Barang tersebut ditetapkan oleh Menteri/Pimpinan Lembaga sesuai kewenangan dan tanggung jawab masing-masing.

Peraturan Menteri Keuangan Nomor 4/PMK.06/2015 tentang Pendelegasian Kewenangan dan Tanggung Jawab Tertentu dari Pengelola Barang Kepada Pengguna Barang, juga mengatur penggunaan Barang Milik Negara, di mana dalam Pasal 3 ayat (1) dinyatakan bahwa kewenangan dan tanggung jawab tertentu dari Pengelola Barang didelegasikan kepada Pengguna Barang, yaitu meliputi:

a. penetapan status penggunaan BMN;

b. pemberian persetujuan Penggunaan Sementara BMN; 
c. pemberian persetujuan atas permohonan Pemindahtanganan BMN meliputi Penjualan dan Hibah BMN, kecuali terhadap BMN yang berada pada Pengguna Barang yang memerlukan persetujuan Presiden/Dewan Perwakilan Rakyat;

d. pemberian persetujuan atas permohonan pemusnahan BMN;

e. pemberian persetujuan atas permohonan penghapusan BMN

Pasal 3 ayat (2) menyatakan pendelegasian kewenangan dan tanggung jawab tersebut harus dilaksanakan oleh Menteri/Pimpinan Lembaga selaku Pengguna Barang sesuai dengan ketentuan Peraturan Perundang-undangan di bidang pengelolaan Barang Milik Negara. Lebih lanjut Pasal 3 ayat (3) menyatakan bahwa Pelaksanaan kewenangan dan tanggung jawab yang didelegasikan tersebut secara fungsional dilakukan oleh:

a. Sekretaris Jenderal/Sekretaris Kementerian/Sekretaris Utama pada Kementerian/Lembaga termasuk Kantor Menteri Koordinator/Kantor Menteri Negara;

b. Jaksa Agung Muda Pembinaan pada Kejaksaan Agung;

c. Asisten Kepala Kepolisian Negara Republik Indonesia Bidang Sarana dan Prasarana pada Kepolisian Negara Republik Indonesia

d. Pimpinan Kesekretariatan/Kepaniteraan pada Lembaga Tinggi Negara

Secara fungsional pelaksanaan kewenangan dan tanggung jawab Menteri/Pimpinan Lembaga selaku Pengguna Barang, dilaksanakan oleh unit Eselon I yang membidangi kesekretariatan. Dengan beragamnya bentuk kelembagaan Kementerian/Lembaga, menurut hemat penulis pengaturan tersebut sudah mengakomodir beragam bentuk kelembagaan yang ada sehingga ketentuan tersebut tidak menghambat dalam pelaksanaannya. Pasal 3 ayat (4) menyatakan bahwa Pengguna Barang tidak dapat menerus limpahkan pendelegasian kewenangan dan tanggung jawab tersebut kepada Kuasa Pengguna Barang. Klasifikasi pendelegasian kewenangan dan tanggung jawab terkait penggunaan BMN diatur dalam Pasal 4 ayat (1) yaitu bahwa Pengguna Barang berwenang dan bertanggung jawab:

a. menetapkan status penggunaan;

b. memberikan persetujuan Penggunaan Sementara.

Pendelegasian kewenangan dan tanggung jawab tersebut, diatur dalam Pasal 4 ayat (2), yaitu dilakukan terhadap:

a. alat utama sistem persenjataan;

b. Barang Milik Negara selain tanah dan/atau bangunan, yang tidak memunyai dokumen kepemilikan, dengan nilai perolehan sampai dengan Rp100.000.000,00 (Seratus Juta Rupiah) per unit/satuan.

Berdasarkan uraian tersebut di atas, apabila dianalisis lebih jauh terhadap kewenangan dan tanggung jawab dalam menetapkan status penggunaan BMN, maka terdapat ketentuan yang bertentangan, yaitu: 
a. Terkait sumber kewenangan dan tanggung jawab yang dimiliki Menteri/Pimpinan Lembaga, Pasal 7 ayat (1) huruf a. dan ayat (2) Peraturan Menteri Keuangan Nomor 246/PMK.06/2014 menyatakan bahwa Menteri/Pimpinan Lembaga selaku Pengguna Barang memiliki kewenangan dan tanggung jawab dalam menetapkan status penggunaan BMN yang berada dalam penguasaannya berupa BMN selain tanah dan/atau bangunan, yang tidak memunyai dokumen kepemilikan, dengan nilai perolehan sampai dengan Rp100.000.000,00 (Seratus Juta Rupiah) per unit/satuan dan alat utama sistem persenjataan. Dalam pasal tersebut seolah-olah kewenangan dan tanggung jawab tersebut melekat pada Pengguna Barang. Hal ini bertentangan dengan Pasal 6 ayat (2) huruf d. Peraturan Pemerintah Nomor 27 Tahun 2014 yang menyatakan bahwa Pengguna Barang Milik Negara berwenang dan bertanggung jawab mengajukan permohonan penetapan status penggunaan BMN yang berada dalam penguasaannya kepada Pengelola Barang. Selain itu Pasal 4 ayat (2) huruf c. dan ayat (3) Peraturan Pemerintah Nomor 27 Tahun 2014 menyatakan bahwa Pengelola Barang dapat mendelegasikan kewenangan dan tanggung jawab tertentu yaitu menetapkan status penguasaan dan penggunaan BMN kepada Pengguna Barang/Kuasa Pengguna Barang. Sehingga menurut penulis kewenangan dan tanggung jawab menetapkan status penggunaan BMN tersebut bukan kewenangan dan tanggung jawab Pengguna Barang tetapi merupakan kewenangan dan tanggung jawab tertentu Pengelola Barang yang didelegasikan kepada Pengguna Barang sebagaimana diatur dalam Pasal 4 Peraturan Menteri Keuangan Nomor 4/PMK.06/2015.

b. Terkait pelaksanaan kewenangan dan tanggung jawab Pengguna Barang dalam menetapkan status penggunaan BMN selain tanah dan/atau bangunan, yang tidak memunyai dokumen kepemilikan, dengan nilai perolehan sampai dengan Rp100.000.000,00 (Seratus Juta Rupiah) per unit/satuan dan alat utama sistem persenjataan, dalam Pasal 7 ayat (4) Peraturan Menteri Keuangan Nomor 246/PMK.06/2014, diatur bahwa Menteri/Pimpinan Lembaga selaku Pengguna Barang dapat menunjuk pejabat di lingkungan kantor pusat dan/atau pejabat di lingkungan instansi vertikal untuk melaksanakan kewenangan dan tanggung jawab menetapkan status penggunaan BMN tersebut. Hal ini menurut penulis bertentangan dengan ketentuan yang diatur dalam Pasal 3 ayat (1) huruf a. dan ayat (4) Peraturan Menteri Keuangan Nomor 4/PMK.06/2015, yang menyatakan bahwa Pengguna Barang tidak dapat meneruslimpahkan pendelegasian kewenangan dan tanggung jawab menetapkan status penggunaan BMN kepada Kuasa Pengguna Barang yang telah dilimpahkan oleh Pengelola Barang kepada Pengguna Barang, sehingga pengaturan penetapan status penggunaan BMN berupa selain 
tanah dan/atau bangunan, yang tidak memunyai dokumen kepemilikan, dengan nilai perolehan sampai dengan Rp100.000.000,00 (seratus juta rupiah) per unit/satuan dan alat utama sistem persenjataan, menjadi tidak jelas.

Berkaitan dengan hal tersebut, Direktorat Jenderal Kekayaan Negara, selaku regulator pengelolaan BMN melakukan pembahasan permasalahan tersebut sebagaimana tertuang dalam Notulensi Rapat Sinkronisasi Peraturan Menteri Keuangan Nomor 246/PMK.06/2014 dan Peraturan Menteri Keuangan Nomor 4/PMK.06/2015 pada tanggal 04 Februari 2015 dan disimpulkan bahwa Peraturan Menteri Keuangan Nomor 246/PMK.06/2014 tidak bertentangan dengan Peraturan Menteri Keuangan Nomor 4/PMK.06/2015 karena kewenangan Pengelola Barang hanya diberikan kepada Pengguna Barang. Pengguna Barang dapat menunjuk (bukan meneruslimpahkan kepada) pejabat struktural di lingkungan kantor pusat/instansi vertikal (bukan sebagai Kuasa Pengguna Barang) dalam menetapkan status penggunaan BMN tersebut. Untuk dapat melakukan kewenangan tersebut, Pengguna Barang perlu membuat surat keputusan penunjukan. Namun demikian, menurut penulis, untuk menghilangkan ketidakjelasan pengaturan perlu dilakukan sinkronisasi dan harmonisasi terhadap kedua peraturan Menteri Keuangan tersebut, sehingga ketika Kementerian/Lembaga akan melaksanakan ketentuan tersebut tidak menimbulkan multitafsir dalam pelaksanaannya.

Terkait regulasi dalam penetapan status penggunaan BMN adalah adanya pengecualian penetapan status penggunaan. Secara prinsip, objek penetapan status penggunaan adalah meliputi seluruh Barang Milik Negara, namun demikian, Peraturan Pemerintah Nomor 27 Tahun 2014, mengatur pengecualian BMN untuk ditetapkan status penggunaannya, yaitu dalam Pasal 15 mengatur bahwa Penetapan Status Penggunaan BMN tidak dilakukan terhadap:

a. Barang Milik Negara berupa :

1) Barang persediaan;

2) Konstruksi dalam pengerjaan; atau

3) Barang yang dari awal pengadaannya direncanakan untuk dihibahkan

b. Barang Milik Negara yang berasal dari dana dekonsentrasi dan dana penunjang tugas pembantuan, yang direncanakan untuk diserahkan

c. Barang Milik Negara lainnya yang ditetapkan lebih lanjut oleh Pengelola Barang

Pada prinsipnya seluruh BMN harus ditetapkan status penggunaannya. Pengecualian dalam menetapkan status penggunaan dilakukan dalam rangka efektifitas dan penyederhanaan dalam birokrasi karena BMN yang dikecualikan tersebut merupakan BMN yang bersifat sementara karena telah habis masa pakainya atau karena BMN tersebut akan dihibahkan. Lebih 
lanjut, Peraturan Menteri Keuangan Nomor 246/PMK.06/2014, memperluas cakupan BMN yang dikecualikan untuk ditetapkan status penggunaannya, yaitu dalam Pasal 8 ayat (2) mengatur bahwa dikecualikan dari objek penetapan status Penggunaan adalah BMN berupa:

a. barang persediaan;

b. Konstruksi Dalam Pengerjaan (KDP);

c. barang yang dari awal pengadaannya direncanakan untuk dihibahkan;

d. barang yang berasal dari dana dekonsentrasi dan dana penunjang tugas pembantuan, yang direncanakan untuk diserahkan;

e. Bantuan Pemerintah Yang Belum Ditetapkan Statusnya (BPYDS); dan

f. Aset Tetap Renovasi (ATR).

Setelah ditetapkannya Peraturan Pemerintah Nomor 27 Tahun 2014, dalam praktik ternyata masih terdapat BMN yang seharusnya juga perlu dikecualikan untuk ditetapkannya status penggunaan seperti perbaikan atau renovasi terhadap bangunan gedung, sehingga dalam Peraturan Menteri Keuangan Nomor 246/PMK.06/2014 hal tersebut telah diakomodir. Pengecualian penetapan status penggunaan BMN sebelumnya tidak dikenal dalam Peraturan Pemerintah Nomor 6 Tahun 2006, di mana penetapan status penggunaan BMN dilakukan terhadap seluruh Barang Milik Negara, sehingga dalam praktiknya seringkali menghambat proses bentuk pengelolaan BMN lainnya karena sebelum diproses sampai kepada proses penghapusan, BMN tersebut harus diusulkan penetapan status penggunaannya kepada Pengelola Barang secara berjenjang melalui Pengguna Barang, hal ini akan memakan waktu yang lama.

Sebagai contoh apabila suatu Kementerian/Lembaga akan memproses hibah BMN yang dari awal perencanaannya memang BMN tersebut untuk dihibahkan, maka sesuai ketentuan, sebelum diusulkan hibah BMN tersebut harus diusulkan penetapan status penggunaannya kepada Pengelola Barang. Padahal BMN tersebut diadakan bukan untuk digunakan untuk melaksanakan tugas dan fungsi Kementerian/Lembaga tersebut, tetapi dari awal perencanaannya untuk dihibahkan kepada pihak lain, sehingga hal ini dapat menghambat proses hibah dan memperpanjang jalur birokrasi. Dengan adanya pengecualian penetapan status penggunaan BMN ini, maka diharapkan proses pengelolaan BMN yang memiliki karakteristik tertentu, misalnya BMN dari awal perencanaannya untuk dihibahkan, menjadi dapat lebih cepat, birokrasi lebih sederhana sehingga pelayanan kepada stakeholder menjadi jauh lebih baik.

Sebagaimana yang telah dijelaskan, Menteri Keuangan selaku Bendahara Umum Negara adalah Pengelola Barang Milik Negara, sehingga Menteri Keuangan memunyai kewenangan dan tanggung jawab untuk menetapkan kebijakan dan pedoman dalam pengelolaan BMN secara keseluruhan. Dalam pelaksanaannya, kewenangan tersebut didelegasikan 
kepada pelaksana fungsional yaitu Direktur Jenderal Kekayaan Negara. Selanjutnya, untuk mempermudah dalam pelaksanaan kewenang tersebut, maka Direktur Jenderal Kekayaan Negara meneruslimpahkan kewenangan dan tanggung jawab tersebut kepada pejabat di bawahnya di lingkungan Direktorat Jenderal Kekayaan Negara untuk dan atas nama Menteri Keuangan manandatangani surat dan/atau Keputusan Menteri Keuangan di bidang Pengelolaan BMN. Ketentuan tersebut telah diatur dalam Keputusan Menteri Keuangan Nomor 218/KM.6/2013 tentang Pelimpahan Sebagian Wewenang Menteri Keuangan Yang Telah Dilimpahkan Kepada Direktur Jenderal Kekayaan Negara kepada Pejabat di Lingkungan Direktorat Jenderal Kekayaan Negara Untuk dan Atas Nama Menteri Keuangan Manandatangani Surat dan/atau Keputusan Menteri Keuangan. Adapun materi kewenangan yang dilimpahkan adalah sebagai berikut:

\section{Tabel 1}

\section{Daftar Wewenang Yang Dilimpahkan}

\begin{tabular}{|c|c|c|}
\hline \begin{tabular}{|l|} 
No \\
\end{tabular} & Pejabat DJKN & Materi Wewenang yang Dilimpahkan \\
\hline 1. & $\begin{array}{l}\text { Direktur Pengelolaan } \\
\text { Kekayaan Negara } \\
\text { dan Sistem Informasi }\end{array}$ & $\begin{array}{l}\text { 1. Penetapan Status Penggunaan BMN pada } \\
\text { Pengguna Barang, persetujuan/penolakan } \\
\text { pengalihan status penggunaan BMN, dan } \\
\text { persetujuan/penolakan penggunaan } \\
\text { sementara BMN oleh Pengguna Barang } \\
\text { Lainnya, berupa: } \\
\text { a. Tanah dan/atau bangunan dengan nilai } \\
\text { BMN yang dihitung secara proporsional } \\
\text { dari nilai buku*) BMN per usulan di } \\
\text { atas Rp5000.000.000,00 sampai dengan } \\
\text { Rp10.000.000.000,00 } \\
\text { b. Selain Tanah dan/atau bangunan dengan } \\
\text { nilai buku BMN per usulan diatas } \\
\text { Rp5.000.000.000,00 sampai dengan } \\
\text { Rp10.000.000.000,00 } \\
\text { 2. Penetapan Status Penggunaan BMN untuk } \\
\text { dioperasikan oleh pihak lain dalam rangka } \\
\text { melaksanakan pelayanan umum sesuai } \\
\text { dengan tugas pokok dan fungsi } \\
\text { Kementerian Lembaga, berupa: } \\
\text { a. Tanah dan/atau bangunan dengan nilai } \\
\text { BMN yang dihitung secara proporsional } \\
\text { dari nilai buku BMN per usulan sampai } \\
\text { dengan Rp10.000.000.000,00 }\end{array}$ \\
\hline
\end{tabular}




\begin{tabular}{|c|c|c|}
\hline No & Pejabat DJKN & Materi Wewenang yang Dilimpahkan \\
\hline & & $\begin{array}{l}\text { b. Selain Tanah dan/atau bangunan dengan } \\
\text { nilai buku BMN per usulan sampai } \\
\text { dengan Rp10.000.000.000,00 }\end{array}$ \\
\hline 3. & $\begin{array}{l}\text { Kepala Kantor } \\
\text { Wilayah DJKN }\end{array}$ & $\begin{array}{l}\text { Penetapan Status Penggunaan BMN pada } \\
\text { Pengguna Barang, persetujuan/penolakan } \\
\text { pengalihan status penggunaan BMN, dan } \\
\text { persetujuan/penolakan penggunaan } \\
\text { sementara BMN oleh Pengguna Barang } \\
\text { Lainnya, berupa: } \\
\text { a. Tanah dan/atau bangunan dengan nilai } \\
\text { BMN yang dihitung secara proporsional } \\
\text { dari nilai buku BMN per usulan di atas } \\
\text { Rp2.500.000.000,00 sampai dengan } \\
\text { Rp5.000.000.000,00 } \\
\text { b. Selain Tanah dan/atau bangunan dengan } \\
\text { nilai buku BMN per usulan di atas } \\
\text { Rp2.500.000.000,00 sampai dengan } \\
\text { Rp5.000.000.000,00 }\end{array}$ \\
\hline 4. & $\begin{array}{lr}\text { Kepala } & \text { Kantor } \\
\text { Pelayanan } & \text { Kekayaan } \\
\text { Negara dan Lelang }\end{array}$ & $\begin{array}{l}\text { Penetapan Status Penggunaan BMN pada } \\
\text { Pengguna Barang, persetujuan/penolakan } \\
\text { pengalihan status penggunaan BMN, dan } \\
\text { persetujuan/penolakan penggunaan } \\
\text { sementara BMN oleh Pengguna Barang } \\
\text { Lainnya, berupa: } \\
\text { a. Tanah dan/atau bangunan dengan nilai } \\
\text { BMN yang dihitung secara proporsional } \\
\text { dari nilai buku BMN per usulan sampai } \\
\text { dengan Rp2.500.000.000,00 } \\
\text { b. Selain Tanah dan/atau bangunan dengan } \\
\text { nilai buku BMN per usulan sampai } \\
\text { dengan Rp2.500.000.000,00 }\end{array}$ \\
\hline
\end{tabular}

Sumber: Materi Sosialisasi KMK 218/KM.6/2013, DJKN

Dalam Pasal 13 Peraturan Menteri Keuangan Nomor 246/PMK.06/2014 diatur bahwa Pengelola Barang melakukan Penetapan Status Penggunaan BMN melalui keputusan yang ditetapkan oleh Pengelola Barang. Keputusan Pengelola Barang tersebut sekurang-kurangnya memuat:

a. pertimbangan penetapan status penggunaan;

b. BMN yang ditetapkan statusnya;

c. pengguna barang;

d. tindak lanjut penetapan status penggunaan BMN. 
Direktur Jenderal Kekayaan Negara melalui Keputusan Nomor 298/KN/2015 tentang Perubahan atas Keputusan Direktur Jenderal Kekayaan Nomor KEP-115/KN/2011 tentang Format dan Bentuk Keputusan atau Surat Persetujuan Pengelolaan Barang Milik Negara di Lingkungan Direktorat Jenderal Kekayaan Negara, memberikan pedoman bagi pejabat yang diberikan kewenangan di lingkungan Direktorat Jenderal Kekayaan Negara antara lain format dan bentuk keputusan Penetapan Status Penggunaan BMN. Dengan keputusan tersebut Pengguna Barang dan Kuasa Pengguna Barang mendapatkan penguasaan terhadap BMN untuk melakukan tindakan hukum yaitu dapat melakukan pemanfaatan atau pemindahtanganan kepada pihak lain dengan syarat harus terlebih dahulu mendapat persetujuan dari Pengelola Barang. Selain kewenangan, dengan ditetapkannya status penggunaan BMN tersebut maka timbul juga kewajiban yang harus dilaksanakan yaitu melakukan monitor dan evaluasi atas optimalisasi penggunaan BMN dan bertanggung jawab atas biaya yang timbul terkait pengamanan dan pemeliharaan BMN yang digunakan tersebut. Berdasarkan hal tersebut, timbul suatu hubungan hukum antara Pengguna Barang maupun Kuasa Pengguna Barang dengan Pengelola Barang yaitu bahwa Pengguna Barang dan Kuasa Pengguna Barang dalam melakukan tindakan pengelolaan BMN seperti melakukan pemanfaatan dan pemindahtanganan harus terlebih dahulu mendapat persetujuan Pengelola Barang.

Terkait kewenangan Menteri/Pimpinan Lembaga selaku Pengguna Barang dalam melaksanakan kewenangannya di bidang pengelolaan BMN, maka di beberapa Kementerian/Lembaga juga telah membuat kebijakan dalam pengelolaan BMN. Pengaturan tersebut berbeda antara Kementerian/Lembaga yang satu dengan lainnya tergantung kebijakan pada Kementerian/Lembaga tersebut, namun demikian harus tetap berpedoman pada peraturan perundang-undangan dibidang pengelolaan BMN. Adapun beberapa contoh keputusan Menteri/Pimpinan Lembaga selaku Pengguna Barang dalam bidang Pengelolaan BMN, yaitu sebagai berikut:

a. Keputusan Menteri Kesehatan Nomor 398/MENKES/SK/X/2013 tentang Pelimpahan Sebagian Wewenang Pengguna Barang Kepada Sekretaris Jenderal, Kepala Biro Keuangan Dan BMN, Sekretaris Direktorat Jenderal, Sekretaris Badan, Sekretaris Inspektorat Jenderal Selaku Kuasa Pengguna Barang Pada Unit Pusat Dan Kepala Kantor/Satuan Kerja Unit Pelaksana Teknis di Lingkungan Kementerian Kesehatan Untuk Dan Atas Nama Menteri Kesehatan.

b. Peraturan Menteri Pekerjaan Umum Nomor 10/PRT/M/2013 tentang Perubahan Atas Peraturan Menteri Pekerjaan Umum Nomor 02/PRT/M/2009 tentang Pedoman Pelaksanaan Penetapan Dan Pengalihan Status Penggunaan, Pemanfaatan, Penghapusan, Dan 
Pemindahtanganan Barang Milik Negara Di Lingkungan Departemen Pekerjaan Umum.

c. Peraturan Menteri Perhubungan Nomor PM.39 Tahun 2011 tentang Petunjuk Pelaksanaan Pengelolaan Barang Milik Negara di Lingkungan Kementerian Perhubungan.

Dari ketiga contoh di atas, terlihat bahwa pada setiap Kementerian/Lembaga berbeda bentuk regulasinya tergantung dari Kementerian/Lembaga masing-masing, ada keputusannya itu dituangkan dalam bentuk pelimpahan wewenang, ada yang dituangkan dalam bentuk pedoman pelaksanaan ada juga yang dituangkan dalam bentuk petunjuk pelaksaan. Namun demikian, kesemuanya itu harus tetap mengacu kepada ketentuan peraturan perundang-undangan di bidang pengelolaan BMN. Selanjutnya regulasi tatacara/prosedur penetapan status penggunaan BMN diatur dalam Peraturan Menteri Keuangan Nomor 246/PMK.06/2014. Secara umum pengaturan ketentuan penetapan status penggunaan BMN dibagi dalam 4(empat) tahap yaitu tahap permohonan, tahap penelitian, tahap penetapan dan tahap pendaftaran. Pengaturan tersebut meliputi tata cara/prosedur penetapan status penggunaan BMN pada Pengelola Barang dan tata cara/prosedur penetapan status penggunaan BMN pada Pengguna Barang. Sebelum dilakukan proses penetapan status penggunaan, maka Pengguna Barang/Kuasa Pengguna Barang harus menyelesaikan dokumen kepemilikan Barang Milik Negara berupa tanah dan/atau bangunan, sebagaimana amanat Undang-undang Nomor 1 Tahun 2004 Pasal 49 ayat 1, yang menyatakan bahwa BMN berupa tanah yang dikuasai oleh Pemerintah Pusat harus disertifikatkan atas nama Pemerintah RI. Sertifikasi BMN berupa tanah ini dilaksanakan oleh lembaga yang berwenang di bidang Pertanahan Nasional, yaitu Badan Pertanahan Nasional (BPN). Untuk penyelesaian dokumen kepemilikan BMN berupa tanah, baik yang belum bersertifikat maupun sudah bersertifikat tetapi belum atas nama Pemerintah Republik Indonesia, maka proses sertifikasinya adalah dengan cara Pengguna Barang/Kuasa Pengguna Barang mengajukan permohonan sertifikasi kepada Kantor Pertanahan setempat.

Terkait sertifikasi BMN berupa tanah, Kementerian Keuangan telah bekerjasama dengan Badan Pertanahan Nasional dan membuat suatu peraturan bersama antara Menteri Keuangan dan Kepala Badan Pertanahan Nasional yaitu Peraturan Menteri Keuangan Nomor 186/PMK.06/2009 dan Peraturan Kepala BPN Nomor 24 Tahun 2009 tentang Sertifikasi BMN Berupa Tanah. Prinsip yang tertuang dalam peraturan bersama tersebut adalah bahwa BMN berupa tanah harus disertipikatkan atas nama Pemerintah Republik Indonesia c.q Kementerian Negara/Lembaga yang menguasai dan/atau menggunakan BMN tersebut. Tujuan yang hendak dicapai dalam peraturan bersama ini adalah memberikan kepastian hukum 
atas BMN berupa tanah, memberikan perlindungan hukum kepada pemegang hak atas tanah, melaksanakan tertib administrasi BMN berupa tanah, dan mengamankan BMN berupa tanah. Untuk dokumen perizinan bangunan, yaitu Izin Mendirikan Bangunan (IMB) maka penyelesaian dokumen tersebut harus dilakukan sebelum proses pembangunan dimulai. Tata cara/prosedur dalam Penetapan Status Penggunaan BMN oleh Pengelola Barang diatur dalam Peraturan Menteri Keuangan Nomor 246/PMK.06/2014 pada Bagian Kedua, dari Pasal 10 sampai dengan Pasal 14, yaitu sebagai berikut:

\section{a. Tahap Permohonan}

Permohonan penetapan status Penggunaan BMN diajukan secara tertulis oleh Pengguna Barang kepada Pengelola Barang paling lama 6 (enam) bulan sejak BMN diperoleh. Sebagai syarat pengajuan usul permohonan penetapan status Penggunaan BMN, maka usulan tersebut harus disertai dokumen sebagai berikut:

1) untuk usulan penetapan status penggunaan BMN berupa tanah, maka harus dilengkapi dengan dokumen kepemilikan berupa sertipikat. Dalam hal BMN yang diusulkan belum memiliki dokumen kepemilikan berupa sertifikat, dapat diganti dengan:

a) fotokopi dokumen kepemilikan lainnya yang setara, seperti Akta Jual Beli (AJB), Girik, Letter C, dan Berita Acara Serah Terima (BAST) terkait perolehan barang;

b) surat pernyataan tanggung jawab bermaterai cukup yang ditandatangani oleh pejabat struktural yang berwenang di lingkungan unit organisasi eselon I pada Kementerian/Lembaga bersangkutan yang menyatakan bahwa tanah tersebut digunakan dalam penyelenggaraan tugas dan fungsi Kementerian/Lembaga;

c) surat keterangan dari Lurah/Camat setempat yang memperkuat pernyataan tersebut, jika ada

d) surat permohonan pendaftaran hak atas tanah dari satuan kerja pada Kementerian/Lembaga kepada Kantor Pertanahan, jika ada.

2) untuk BMN berupa bangunan, maka dokumen yang harus dilengkapi adalah:

a) fotokopi Izin Mendirikan Bangunan (IMB). ;

b) fotokopi dokumen perolehan; dan

c) fotokopi dokumen lainnya, seperti Berita Acara Serah Terima (BAST) perolehan barang;

terhadap BMN berupa bangunan yang tidak memiliki Izin Mendirikan Bangunan (IMB), dokumen perolehan, dan/atau dokumen lainnya, dokumen tersebut dapat diganti dengan Surat Pernyataan Tanggung 
Jawab bermeterai cukup yang ditandatangani oleh pejabat struktural yang berwenang pada Kementerian/Lembaga bersangkutan yang menyatakan bahwa bangunan terse but digunakan dalam penyelenggaraan tugas dan fungsi Kementerian/ Lembaga.

3) untuk BMN berupa tanah dan bangunan:

a) fotokopi dokumen kepemilikan tanah berupa sertipikat;

b) fotokopi Izin Mendirikan Bangunan (IMB);

c) fotokopi dokumen perolehan; dan

d) fotokopi dokumen lainnya, seperti Berita Acara Serah Terima (BAST) perolehan barang;

4) untuk BMN selain tanah dan/atau bangunan:

a) yang memiliki dokumen kepemilikan:

(1)fotokopi dokumen kepemilikan, seperti Pemilikan Kendaraan Bermotor (BPKB), pemilikan pesawat terbang, bukti pemilikan laut, atau dokumen lain yang setara dengan kepemilikan; dan

(2) fotokopi dokumen lainnya, seperti Surat Tanda Nomor Kendaraan (STNK) atau Berita Acara Serah Terima (BAST) terkait perolehan barang;

b) yang tidak memiliki dokumen kepemilikan dengan nilai perolehan di atas Rp100.000.000,00 (Seratus Juta Rupiah) per unit/ satuan, yakni fotokopi Berita Acara Serah Terima (BAST) perolehan barang dan dokumen lainnya.

5) untuk BMN yang dari awal pengadaannya direncanakan untuk dilakukan pemindahtanganan dengan cara Penyertaan Modal Pemerintah Pusat (PMPP):

a) fotokopi dokumen penganggaran, seperti Daftar Isian Pelaksanaan Anggaran (DIPA);

b) fotokopi hasil audit Aparat Pengawasan Intern Pemerintah atau Badan Pemeriksa Keuangan Republik Indonesia;

c) fotokopi dokumen kepemilikan berupa sertipikat, untuk BMN berupa tanah;

d) fotokopi Izin Mendirikan Bangunan (1MB), untuk BMN berupa bangunan;

e) fotokopi dokumen perolehan bangunan, untuk BMN berupa bangunan;

f) fotokopi dokumen lainnya, seperti Berita Acara Serah Terima (BAST) perolehan barang; dan

g) fotokopi Berita Acara Serah Terima (BAST) pengelolaan sementara BMN, dalam hal BMN yang akan dijadikan Penyertaan Modal 
Pemerintah Pusat secara fisik sudah tidak berada dalam penguasaan Pengguna Barang;

6) dalam hal dokumen penganggaran berupa Daftar isian Pelaksanaan Anggaran (DIPA) tidak secara tegas menyatakan BMN direncanakan untuk dijadikan Penyertaan Modal Pemerintah Pusat (PMPP), maka permohonan didukung dengan:

a) fotokopi Kerangka Acuan Kerja (KAK);

b) fotokopi Rencana I\{erja dan Anggaran Kementerian/Lembaga (RKA$\mathrm{K} / \mathrm{L}$ ); atau

c) fotokopi Petunjuk Operasional Kegiatan (POK);

Seluruh fotokopi dokumen disertai dengan surat keterangan dari pejabat struktural yang berwenang pada Kementerian/Lembaga bersangkutan yang menyatakan kebenaran fotokopi dokumen tersebut.

\section{b. Tahap Penelitian}

Setelah usulan diterima maka Pengelola Barang melakukan penelitian atas permohonan tersebut. Penelitian dilakukan terhadap kelengkapan dan kesesuaian dokumen yang dipersyaratkan. Dalam hal hasil penelitian belum mencukupi, maka Pengelola Barang dapat:

1) meminta keterangan atau data tambahan kepada Pengguna Barang yang mengajukan permohonan penetapan status Penggunaan BMN;

2) meminta konfirmasi dan klarifikasi kepada instansi terkait; dan/atau

3) melakukan pengecekan lapangan.

Kegiatan tersebut hanya dilakukan terhadap BMN berupa tanah dan/atau bangunan serta BMN selain tanah dan/atau bangunan yang memiliki dokumen kepemilikan atau dokumen lain yang setara.

\section{c. Tahap Penetapan}

Setelah hasil penelitian lengkap, maka Pengelola Barang melakukan penetapan status penggunaan BMN melalui Keputusan Pengelola Barang yang sekurang-kurangnya memuat:

1) pertimbangan penetapan status Penggunaan;

2) BMN yang ditetapkan statusnya;

3) Pengguna Barang; dan

4) tindak lanjut penetapan status Penggunaan BMN.

Apabila Pengelola Barang tidak menyetujui permohonan Pengguna Barang maka Pengelola Barang memberitahukan secara tertulis kepada Pengguna Barang disertai dengan alasannya. 


\section{d. Tahap Pendaftaran}

Setelah ditetapkan status penggunaan BMN oleh Pengelola Barang maka berdasarkan surat keputusan tersebut, Pengguna Barang melakukan pendaftaran BMN ke dalam Daftar Barang pada Pengguna Barang.

Selain diatur tata cara/prosedur penetapan status penggunaan BMN oleh Pengelola Barang, Peraturan Menteri Keuangan Nomor 246/PMK.06/2014 juga mengatur bagaimana Pengelola Barang dapat menetapkan status penggunaan BMN pada Pengguna Barang. Pasal 15 mengatur bahwa Penetapan status penggunaan BMN tersebut dilaksanakan dalam kondisi tertentu dan tanpa didahului adanya proses usulan penetapan status Penggunaan dari Pengguna Barang. Kondisi tersebut dilakukan terhadap BMN antara lain:

1) adanya sengketa di Pengadilan;

2) adanya sengketa pertanahan di Badan Pertanahan Nasional;

3) penetapan BMN yang berasal dari perolehan lainnya yang sah; atau

4) penetapan BMN yang berasal dari pengalihan status Penggunaan BMN.

Terkait regulasi terkait tata cara/prosedur penetapan status penggunaan BMN oleh Pengguna Barang diatur dalam Pasal 16 sampai dengan Pasal 17, dengan mekanisme sebagai berikut:

1) kuasa pengguna barang mengajukan permohonan secara tertulis kepada pengguna barang, dengan melampirkan dokumen terkait perolehan barang;

2) pengguna barang melakukan penelitian atas permohonan Kuasa Pengguna Barang;

3) dalam hal berdasarkan hasil penelitian, permohonan Kuasa Pengguna Barang dapat disetujui, Pengguna Barang melakukan penetapan status Penggunaan BMN melalui keputusan Pengguna Barang yang memuat sekurang-kurangnya memuat:

a) pertimbangan penetapan status Penggunaan;

b) BMN yang ditetapkan statusnya;

c) Pengguna Barang; dan

d) tindak lanjut penetapan status Penggunaan BMN.

4) Keputusan Pengguna tersebut harus dilaporkan kepada Pengelola Barang paling lama 1 (satu) bulan sejak ditetapkan.

Berdasarkan uraian di atas, terkait regulasi penetapan status penggunaan $\mathrm{BMN}$, penulis berpendapat bahwa secara hierarki peraturan perundang-undangan mengenai regulasi penetapan status penggunaan BMN dari Undang-undang Nomor 17 Tahun 2003, Undang-undang Nomor 1 Tahun 2004 dan Peraturan Pemerintah Nomor 27 Tahun 2014 dan Peraturan Teknisnya yaitu Peraturan Menteri Keuangan Nomor 246/PMK.06/2014, 
Peraturan Menteri Keuangan Nomor 4/PMK.06/2015 dan Keputusan Menteri Keuangan Nomor 218/KM.06/2013, tidak terjadi dis-harmoni regulasi dalam penetapan status penggunaan BMN. Dengan kata lain hal ini telah memenuhi amanat yang terdapat dalam Undang-undang Nomor 12 Tahun 2011 tentang Pembentukan Peraturan Perundang-undangan, yaitu bahwa pada prinsipnya peraturan perundang-undangan yang lebih rendah tingkatannya tidak boleh bertentangan dengan peraturan yang lebih tinggi tingkatannya (lex superiori derogate inferioeri). Namun demikian perlu dilakukan sinkronisasi dan harmonisasi terhadap beberapa ketentuan yang diatur dalam Peraturan Menteri Keuangan Nomor 246/PMK.06/2014 dan Peraturan Menteri Keuangan Nomor 4/PMK.06/2015 agar tidak menimbulkan ketidakjelasan dan multitafsir dalam pelaksanaannya.

\section{Pelaksanaan Penetapan Status Penggunaan Barang Milik Negara dalam Rangka Optimalisasi Penerimaan Negara di Kantor Wilayah DJKN Provinsi Lampung dan Provinsi Bengkulu}

Kantor Wilayah DJKN Provinsi Lampung dan Provinsi Bengkulu selaku instansi vertikal Direktorat Jenderal Kekayaan Negara, berdasarkan Peraturan Menteri Keuangan Nomor 170/PMK.01/2012 tentang Organisasi dan Tata Kerja Instansi Vertikal Direktorat Jenderal Kekayaan Negara memunyai tugas melaksanakan koordinasi, bimbingan teknis, pengendalian, evaluasi dan pelaksanaan tugas di bidang kekayaan negara, piutang negara dan lelang. Wilayah kerja Kantor Wilayah DJKN Provinsi Lampung dan Provinsi Bengkulu meliputi Satuan Kerja yang ada di Provinsi Lampung dan Provinsi Bengkulu. Kanwil DJKN membawahi 3 (tiga) Kantor Pelayanan Kekayaan Negara dan Lelang (KPKNL) yaitu KPKNL Kota Bandar Lampung, KPKNL Kota Metro dan KPKNL Provinsi Bengkulu. Dalam melaksanakan tugas tersebut Kantor Wilayah DJKN Provinsi Lampung dan Provinsi Bengkulu menyelenggarakan fungsi sebagaimana diatur dalam Pasal 3 Peraturan Menteri Keuangan Nomor 170/PMK.1/2012, yaitu:

a. pemberian bimbingan teknis, pemantauan dan evaluasi pelaksanaan di bidang kekayaan negara;

b. pemberian bimbingan teknis, supervisi, pemantauan dan evaluasi pelaksanaan di bidang penilaian;

c. pemberian bimbingan teknis, penggalian potensi, pemantauan dan evaluasi pelaksanaan pengurusan piutang negara;

d. pemberian bahan pertimbangan atas usul penghapusan, keringanan hutang, pencegahan, paksa badan atau penyelesaian piutang negara;

e. pemberian bimbingan teknis pengelolaan barang jaminan dan pemeriksaan harta kekayaan atau barang jaminan yang tidak diketemukan milik penanggung hutang atau penjamin hutang; 
f. pemberian bimbingan teknis, penggalian potensi, pemantauan, evaluasi dan verifikasi lelang serta pengembangan lelang;

g. pemberian pelayanan bantuan hukum di bidang kekayaan negara, penilaian, piutang negara dan lelang;

h. pemberian bimbingan teknis pemantauan, evaluasi dan pelaksanaan pelayanan informasi serta pelaksanaan verifikasi pengurusan piutang negara dan lelang;

i. pembinaan terhadap Penilai, Usaha Jasa Lelang dan Profesi Pejabat Lelang;

j. pelaksanaan pengawasan teknis pengelolaan kekayaan negara, penilaian, pengurusan piutang negara dan lelang;

k. pelaksanaan penilaian dan pengurusan piutang negara; dan

1. pelaksanaan administrasi Kantor Wilayah.

Keputusan Direktur Jenderal Kekayaan Negara Nomor 147/KN/2015 tentang Rencana Strategis DJKN Tahun 2015-2019 menjadi pedoman bagi Kanwil DJKN Provinsi Lampung dan Provinsi Bengkulu untuk mewujudkan visi DJKN di wilayah Provinsi Lampung dan Provinsi Bengkulu yaitu "Menjadi pengelola kekayaan negara yang profesional dan akuntabel untuk sebesar-besar kemakmuran rakyat". Guna mencapai visi tersebut DJKN memunyai rumusan misi yang menjadi kewajiban bagi Kanwil DJKN Provinsi Lampung dan Provinsi Bengkulu untuk melaksanakannya di wilayah Provinsi Lampung dan Provinsi Bengkulu, yaitu:

a. mewujudkan optimalisasi penerimaan, efisiensi pengeluaran, dan efektivitas pengelolaan kekayaan Negara;

b. mengamankan kekayaan negara secara fisik, administrasi, dan hukum;

c. meningkatkan tata kelola dan nilai tambah pengelolaan investasi pemerintah;

d. mewujudkan nilai kekayaan negara yang wajar dan dapat dijadikan acuan dalam berbagai keperluan;

e. melaksanakan pengurusan piutang negara yang efektif, efisien, transparan, dan akuntabel;

f. mewujudkan lelang yang efisien, transparan, akuntabel, adil, dan kompetitif sebagai instrumen jual beli yang mampu mengakomodasi kepentingan masyarakat.

Sesuai program utama rencana strategi Tahun 2010-2014, Kanwil DJKN Provinsi Lampung dan Provinsi Bengkulu telah melakukan pengelolaan kekayaan Negara, penyelesaian pengurusan piutang Negara, dan pelayanan lelang yang profesional, tertib, tepat guna, dan optimal serta mampu membangun citra baik bagi stakeholder di Provinsi Lampung dan Provinsi Bengkulu. Kegiatan diukur dalam indikator yang menjadi fokus kegiatan utama, yaitu sebagai berikut: 
a. penerimaan negara dari biaya administrasi pengurusan piutang negara dan bea lelang;

b. jumlah PNDS dan pokok lelang;

c. pemberian bimbingan teknis dan penelaahan permasalahan dibidang kekayaan Negara, penilaian, piutang negara, lelang, dan hukum;

d. penyelesaian permohonan pengelolaan kekayaan Negara;

e. laporan hasil penilaian yang dapat diselesaikan sesuai dengan standar penilaian.

Sampai dengan Tahun 2014 nilai aset yang dikelola dan/atau digunakan oleh \pm 895 satuan kerja di wilayah Provinsi Lampung dan Provinsi Bengkulu adalah sebesar Rp37,1 triliun rupiah. Adapun perkembangan nilai aset tersebut adalah sebagai berikut:

Gambar 1

Perkembangan Nilai Aset yang Dikelola

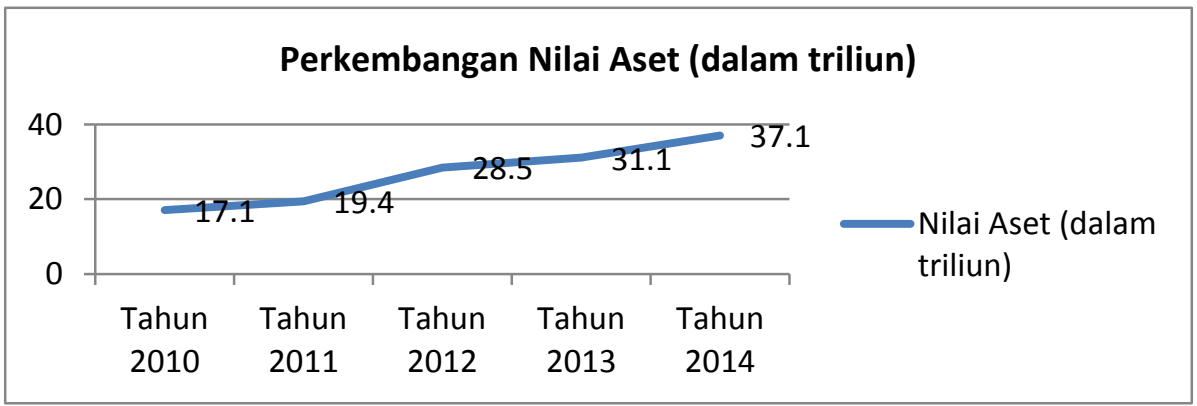

Sumber: Renstra Kanwil DJKN 2015-2019

Salah satu kegiatan utama dalam pengelolaan kekayaan Negara adalah berupa utilisasi kekayaan Negara. Nilai kekayaan negara yang diutilisasi diperoleh dari nilai kekayaan negara yang ditetapkan utilisasinya dengan rincian sebagai berikut:

a. utilisasi melalui pemanfaatan kekayaan negara diperoleh dari:

1) Nilai Barang Milik Negara yang disewakan

2) Nilai Barang Milik Negara yang di-KSP-kan

3) Nilai Barang Milik Negara yang di-BGS/BSG-kan

4) Nilai Barang Milik Negara yang di-pinjampakai-kan

b. utilisasi melalui penetapan status penggunaan diperoleh dari:

1) Nilai Barang Milik Negara yang ditetapkan status penggunaannya

2) Nilai Barang Milik Negara yang ditetapkan statusnya karena hibah masuk 
3) nilai aset yang ditetapkan statusnya yang berasal dari aset KKKS, aset eks. Kelolaan PT. PPA, dan aset eks. BPPN

c. utilisasi melalui penetapan Barang Milik Negara melalui hibah untuk kepentingan sosial, keagamaan, kemanusiaan, dan penyelenggaraan Pemerintah Daerah

d. utilisasi melalui tukar-menukar diperoleh dari nilai aset baru hasil tukar menukar

e. utilisasi melalui penyertaan modal pemerintah dari nilai aset yang dikonversi sebagai penyertaan modal pemerintah

Sampai dengan Tahun 2014 nilai kekayaan negara yang telah diutilisasi di lingkungan Kanwil DJKN Provinsi Lampung dan Provinsi Bengkulu sebesar Rp887,12 Miliar. Berikut ini perkembangan nilai kekayaan negara yang diutilisasi sampai dengan Tahun 2014 pada Kanwil DJKN Provinsi Lampung dan Provinsi Bengkulu.

Gambar 2.

Nilai Kekayaan yang di Utilisasi

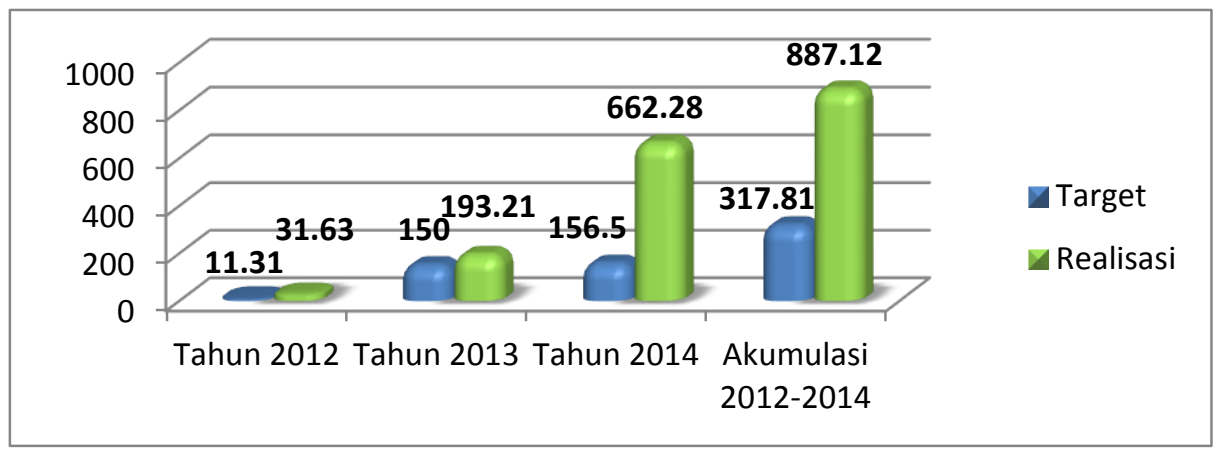

Sumber: Renstra Kanwil DJKN 2015-2019

Apabila dibandingkan antara nilai aset yang dikelola dan/atau digunakan oleh satuan kerja di lingkungan Provinsi Lampung dan Provinsi Bengkulu yaitu sebesar Rp37,1 triliun dan nilai yang telah diutilisasi sampai dengan Tahun 2014 sebesar Rp886,12 miliar, maka akan tergambar bahwa aset yang telah diutiliasai sangat kecil yaitu hanya $\pm 2,38 \%$. Hal ini juga menggambarkan masih sedikitnya Barang Milik Negara yang telah ditetapkan status penggunaannya. Sedangkan untuk Tahun 2015, Kanwil DJKN Provinsi Lampung dan Provinsi Bengkulu telah menetapkan status penggunaan $\mathrm{BMN}$ terhadap 12 permohonan Kemeterian/Lembaga dengan nilai Rp45.984.760.443,00, dengan perincian sebagai berikut:

\section{Tabel 2}




\section{Penetapan Status Penggunaan BMN Tahun 2015}

\begin{tabular}{|c|c|c|c|}
\hline No & Pengguna Barang & Jenis Aset & Nilai \\
\hline 1. & $\begin{array}{l}\text { Kantor Wilayah } \\
\text { Kementerian Agama } \\
\text { Provinsi Bengkulu }\end{array}$ & $\begin{array}{l}\text { Selain Tanah } \\
\text { dan/atau Bangunan }\end{array}$ & $2.540 .960 .035,00$ \\
\hline 2. & $\begin{array}{l}\text { Pengadilan Agama } \\
\text { Lebong, Bengkulu }\end{array}$ & Bangunan Gedung & $4.994 .487 .000,00$ \\
\hline 3. & $\begin{array}{l}\text { Politeknik Negeri } \\
\text { Lampung }\end{array}$ & Bangunan Gedung & $3.513 .954 .813,00$ \\
\hline 4. & $\begin{array}{l}\text { UPT Mineral Lampung, } \\
\text { LIPI }\end{array}$ & Bangunan Gedung & $4.788 .267 .440,00$ \\
\hline 5. & $\begin{array}{l}\text { Politeknik Negeri } \\
\text { Lampung }\end{array}$ & Bangunan Gedung & $4.523 .301 .195,00$ \\
\hline 6. & $\begin{array}{l}\text { Rutan Kelas II Kota } \\
\text { Agung }\end{array}$ & $\begin{array}{l}\text { Tanah dan } \\
\text { Bangunan }\end{array}$ & $2.781 .111 .755,00$ \\
\hline 7. & $\begin{array}{l}\text { Badan Narkotika } \\
\text { Nasional Lampung } \\
\text { Selatan }\end{array}$ & Bangunan Gedung & $3.162 .186 .240,00$ \\
\hline 8. & $\begin{array}{l}\text { Balai Taman Nasional } \\
\text { Way Kambas }\end{array}$ & $\begin{array}{l}\text { Tanah dan } \\
\text { Bangunan }\end{array}$ & $3.904 .750 .000,00$ \\
\hline 9. & $\begin{array}{l}\text { Loka Monitor Spektrum } \\
\text { Frekuensi Radio } \\
\text { Bengkulu }\end{array}$ & $\begin{array}{l}\text { Selain Tanah } \\
\text { dan/atau Bangunan }\end{array}$ & $3.594 .102 .499,00$ \\
\hline 10. & $\begin{array}{l}\text { Bandar Udara Muko- } \\
\text { Muko, Bengkulu }\end{array}$ & Bangunan Gedung & $4.998 .745 .550,00$ \\
\hline 11. & $\begin{array}{l}\text { Satker Penataan } \\
\text { Bangunan dan } \\
\text { Lingkungan Bengkulu }\end{array}$ & $\begin{array}{l}\text { Selain Tanah dan } \\
\text { Bangunan }\end{array}$ & $3.915 .439 .666,00$ \\
\hline 12. & $\begin{array}{l}\text { Balai Besar Perikanan } \\
\text { Budidaya Laut } \\
\text { Lampung }\end{array}$ & $\begin{array}{l}\text { Tanah dan } \\
\text { Bangunan }\end{array}$ & $3.267 .454 .250,00$ \\
\hline \multicolumn{3}{|c|}{ JUMLAH } & 45.984.760.443,00 \\
\hline
\end{tabular}

Sumber: Kanwil DJKN Provinsi Lampung dan Provinsi Bengkulu

Berdasarkan hasil wawancara dengan Kepala Bidang Pengelolaan Kekayaan Negara, disampaikan bahwa utilisasi kekayaan negara yang didalamnya termasuk nilai BMN yang ditetapkan status penggunaannya berasal dari data kinerja Kanwil DJKN dan KPKNL, sehingga data nilai penetapan status penggunaan BMN tersebut hanya yang ditetapkan oleh Kanwil DJKN dan KPKNL. Sedangkan penetapan status penggunaan BMN 
yang merupakan kewenangan Kantor Pusat DJKN, kadangkala tidak tercatat dan terpantau oleh Kanwil DJKN, padahal penetapan status penggunaan BMN yang menjadi kewenangan kantor pusat DJKN nilainya besar yaitu diatas Rp5.000.000.000,00 (Lima Miliar Rupiah) per usulan. Selain itu penetapan status penggunaan BMN yang menjadi kewenangan Pengguna Barang, walaupun nilainya kecil yaitu BMN selain tanah dan/atau bangunan yang tidak punya bukti kepemilikan dengan nilai di bawah Rp100.000.000,00 (Seratus Juta Rupiah), namun jumlah cukup signifikan. Lebih lanjut beliau menyampaikan bahwa DJKN selaku pengelola kekayaan negara telah mengembangkan aplikasi berbasis internet sejak tahun 2014 yaitu aplikasi Sistem Informasi Manajemen Aset Negara (SIMAN) dan aplikasi tersebut telah diimplementasikan untuk melaksanakan rekonsiliasi data BMN pada Semester I Tahun 2015. Sedangkan aplikasi yang sudah yaitu Sistem Informasi Manajemen Akuntasi Keuangan Barang Milik Negara (SIMAK BMN) yang merupakan subsistem dari Sistem Akuntasi Instansi (SAI) berfungsi sebagai pendukung dalam pelaporan pertanggungjawaban keuangan pemerintah pusat (LKPP) pada Kementerian/Lembaga. Diharapkan aplikasi SIMAN yang disinergikan dengan aplikasi SIMAK BMN dapat mendukung pengelolaan BMN khususnya terkait pelaksanaan pengawasan dan pengendalian dalam penetapan status penggunaan BMN sehingga pengelolaan BMN akan semakin baik, akuntabel, dan tertib fisik, tertib administrasi dan tertib hukum dalam pengelolaan BMN dapat segera terwujud.

Berdasarkan hasil wawancara dengan Kepala Seksi di Bidang Pengelolaan Kekayaan Negara, Kanwil DJKN Provinsi Lampung dan Provinsi Bengkulu telah menerapkan Standard Operating Prosedur (SOP) dalam memproses permohonan penetapan status penggunaan BMN. SOP dalam penetapan status penggunaan $\mathrm{BMN}$ terdiri atas:

a. SOP penetapan status penggunaan BMN berupa tanah dan/atau bangunan dengan norma waktu penyelesaian selama 6 hari kerja dihitung sejak permohonan diterima dan lengkap. SOP ini merupakan salah satu layanan unggulan dan menjadi Indikator Kinerja Utama (IKU) Kanwil DJKN Provinsi Lampung dan Provinsi Bengkulu di Bidang Pengelolaan Kekayaan Negara;

b. SOP penetapan status penggunaan BMN selain tanah dan/atau bangunan dengan norma waktu 6 hari kerja; dan

c. SOP penetapan status penggunaan BMN yang dioperasikan pihak lain dalam rangka menjalankan pelayanan umum sesuai tugas pokok dan fungsi Kementerian/Lembaga.

Lebih lanjut dijelaskan bahwa untuk meningkatkan kesadaran dan kepatuhan satuan kerja di Provinsi Lampung dan Provinsi Bengkulu dalam memenuhi ketentuan penggunaan BMN yaitu BMN harus ditetapkan status 
penggunaannya, maka Kanwil DJKN Provinsi Lampung dan Provinsi Bengkulu mensyaratkan setiap permohonan pengelolaan BMN, baik itu permohonan pemanfaatan BMN, Pemindahtanganan BMN baik berupa penjualan secara lelang maupun hibah ataupun permohonan pengelolaan BMN lain, terhadap BMN tersebut harus sudah ditetapkan status penggunaannya yang dibuktikan dengan adanya surat keputusan penetapan status penggunaan BMN. Ditetapkannya status penggunaan BMN, maka Kementerian/Lembaga telah sah menggunakan BMN tersebut. Selain itu terhadap biaya-biaya yang timbul dalam penggunaan BMN, seperti biaya pemeliharaan dan dilakukannya optimalisasi penggunaan BMN, antara lain dimanfaatkan dengan cara sewa, dalam rangka penerimaan negara dapat dipertanggungjawabkan. Dalam kurun waktu 2014 sampai dengan 2015, penerimaan negara yang berasal dari pengelolaan BMN antara lain pemanfaatan berupa sewa dan pemindahtanganan melalui penjualan secara lelang di lingkungan Kanwil DJKN Provinsi Lampung dan Provinsi Bengkulu menghasilkan Penerimaan Negara Bukan Pajak (PNBP) sebesar Rp5.053.281.841,00. Walaupun secara nominal nilai yang dihasilkan tidak besar, namun apabila aset yang dikelola sudah optimal maka bukan tidak mungkin penerimaan negara dari pengelolaan BMN akan meningkat signifikan. Berikut tabel penerimaan negara dari hasil pengelolaan BMN kurun waktu 2014-2015.

Tabel 3

Penerimaan Negara dari Pengelolaan BMN

Tahun 2014-2015

\begin{tabular}{|l|l|r|r|r|r|}
\hline \multirow{2}{*}{ No } & \multirow{2}{*}{ Unit Kerja } & \multicolumn{2}{|c|}{ Pemanfaatan BMN } & \multicolumn{2}{c|}{ Penjualan BMN } \\
\cline { 3 - 6 } & Jmlh & \multicolumn{1}{c|}{ Nilai } & Jmlh & \multicolumn{1}{c|}{ Nilai } \\
\hline 1. & Kanwil DJKN & 1 & $450.500 .000,00$ & 3 & $45.502 .812,00$ \\
\hline 2. & $\begin{array}{l}\text { KPKNL } \\
\text { Bengkulu }\end{array}$ & - & & 41 & $950.876 .276,00$ \\
\hline 3. & $\begin{array}{l}\text { KPKNL B. } \\
\text { Lampung }\end{array}$ & 25 & $1.191 .422 .000,00$ & 110 & $1.650 .064 .277,00$ \\
\hline 4. & KPKNL Metro & 4 & $95.492 .000,00$ & 31 & $669.424 .476,00$ \\
\hline \multicolumn{2}{r}{ JUMLAH } & $\mathbf{3 0}$ & $\mathbf{1 . 7 3 7 . 4 1 4 . 0 0 0 , 0 0}$ & $\mathbf{1 8 5}$ & $\mathbf{3 . 3 1 5 . 8 6 7 . 8 4 1 , 0 0}$ \\
\hline
\end{tabular}

Sumber: Kanwil DJKN Lampung dan Bengkulu

Terkait optimalisasi, pada dasarnya BMN diadakan untuk digunakan dalam rangka melaksanakan atau menunjang pelaksanaan tugas dan fungsi dari masing-masing Kementerian/Lembaga. Hal ini sesuai dengan ketentuan dalam Pasal 42 ayat (2) Undang-Undang Nomor 1 Tahun 2004 yang menyatakan bahwa Menteri/pimpinan lembaga adalah Pengguna Barang bagi Kementerian Negara/ Lembaga yang dipimpinnya. Mengacu pada hal 
tersebut, maka dalam pelaksanaan pengelolaan BMN, BMN yang dimiliki dan dikuasai oleh suatu Kementerian/ Lembaga hakikatnya digunakan hanya sebatas untuk kepentingan tugas dan fungsi Kementerian/Lembaga yang bersangkutan. Penguasaan atas BMN pada suatu Kementerian/Lembaga terdapat kondisi BMN yang dikuasai Kementerian/Lembaga tersebut kurang produktif dan belum termanfaatkan atau kurang optimal pemanfaatannya, bahkan terdapat beberapa BMN yang sama sekali tidak termanfaatkan atau tidak produktif dan terindikasi sebagai asset idle. Atas kondisi tersebut, tentunya hanya menambahkan beban bagi negara terkait beban yang ditimbulkan antara lain berupa biaya pemeliharaan dan pengamanan serta biaya-biaya lain.

Pasal 49 ayat (1) Undang-Undang Nomor 1 Tahun 2004 mengamanatkan bahwa BMN berupa tanah dan/atau bangunan yang tidak digunakan untuk kepentingan tugas dan fungsi kementerian/lembaga wajib diserahkan pengelolaannya kepada Pengelola Barang. Atas penyerahan tanah dan bangunan dari Pengguna Barang dimaksud, Pengelola Barang harus memprioritaskan pengelolaan BMN tersebut untuk mendukung dan melaksanakan fungsi pelayanan melalui pengalihan status penggunaan kepada Pengguna Barang lain yang membutuhkan. Ini merupakan prinsip utama dalam Penggunaan BMN yaitu suatu BMN dikatakan optimal apabila BMN yang ada digunakan sepenuhnya untuk kepentingan tugas dan fungsi dari Kementerian/Lembaga. Lebih lanjut, dalam hal tidak ada Pengguna Barang lain yang membutuhkan tanah dan bangunan tersebut, Pengelola Barang dan Pengguna Barang dengan persetujuan Pengelola Barang dapat melakukan tindakan optimalisasi BMN untuk mendukung fungsi budgeter yaitu untuk penerimaan negara berupa Penerimaan Negara Bukan Pajak (PNBP) antara lain melalui Pemanfaatan BMN yang merupakan pendayagunaan BMN yang tidak digunakan untuk penyelenggaraan tugas dan fungsi Kementerian/Lembaga dengan tidak mengubah status kepemilikan, langkah Pemanfaatan BMN tersebut sekaligus sebagai salah satu upaya untuk meningkatkan kinerja dan nilai BMN yang dimiliki. Kalimat tidak mengubah status kepemilikan pada pengertian di atas bermakna bahwa setiap keputusan/persetujuan Pemanfataan atas BMN yang diambil tidak diikuti dengan beralihnya kepemilikan atas BMN tersebut. Dengan demikian, selama masa Pemanfaatan sampai dengan berakhirnya perjanjian Pemanfaatan, status kepemilikan atas BMN dimaksud tetap berada pada Pemerintah Republik Indonesia.

Bentuk lain optimalisasi BMN dalam rangka penerimaan negara adalah penjualan BMN. Penjualan adalah pengalihan kepemilikan BMN kepada pihak lain dengan menerima penggantian dalam bentuk uang. Penjualan dilakukan terhadap BMN yang sudah tidak digunakan untuk kepentingan penyelenggaraan tugas dan fungsi Kementerian/Lembaga atau 
tidak dimanfaatkan oleh pihak lain dan secara ekonomis lebih menguntungkan bagi negara apabila dijual. Penjualan BMN dilakukan misalnya terhadap BMN yang dalam kondisi rusak berat, di mana apabila dipertahankan BMN tersebut maka biaya yang dikeluarkan untuk memperbaikinya jauh lebih besar sehingga tidak efisien. Berdasarkan uraian tersebut penulis berpendapat bahwa pada dasarnya optimalisasi BMN tujuan utamanya adalah bahwa BMN tersebut digunakan sepenuhnya untuk mendukung tugas dan fungsi Kementerian/Lembaga, sedangkan optimalisasi BMN melalui pemanfaatan dan penjualan yang dapat menghasilkan penerimaan negara berupa PNBP dilaksanakan apabila BMN tersebut sudah tidak diperlukan dan dipergunakan lagi untuk penyelenggaraan tugas dan fungsi Kementerian/Lembaga tersebut. Untuk mendukung terwujudnya BMN yang optimal, Kanwil DJKN Lampung dan Bengkulu telah mengimplementasikan Aplikasi SIMAN, yaitu suatu aplikasi berbasis internet dengan database yang terpusat yang dapat diakses oleh Pengelola Barang maupun Pengguna Barang dalam melaksanakan pengelolaan BMN. Dengan database yang terpusat maka data atau informasi yang dihasilkan akan akurat dan akuntabel serta realtime. Adapun keunggulan aplikasi SIMAN adalah sebagai berikut:

a. fungsinya tidak hanya terbatas penatausahaan BMN seperti aplikasi SIMAK-BMN tetapi fungsi-fungsi pengelolaan BMN lainnya sudah terdapat dalam aplikasi SIMAN;

b. adanya Informasi detail terhadap BMN sehingga riwayat aset dapat disusun dengan mudah;

c. dokumen-dokumen yang mendukung legalitas suatu aset dapat terdokumentasi dengan baik melalui digitalisasi aset;

d. proses pengelolaan $\mathrm{BMN}$ dapat termonitor secara realtime; dan

e. dalam melakukan pencarian data BMN (asset tracking) dapat dilakukan secara cepat dan mudah

Dengan diimplementasikannya aplikasi SIMAN tersebut penulis optimis bahwa optimalisasi BMN dapat segera terwujud karena fungsi pengawasan dan pengendalian yang dilaksanakan oleh Pengelola Barang dan Pengguna Barang terhadap BMN menjadi lebih mudah. Dengan terwujudnya optimalisasi BMN maka tertib fisik, tertib administrasi dan tertib hukum dalam pengelolaan BMN dapat segera terwujud.

Namun demikian, pada saat ini dalam pelaksanaan pengelolaan BMN, Kanwil DJKN Provinsi Lampung dan Provinsi Bengkulu masih memiliki hambatan dan kendala yang dihadapi, baik yang berasal dari eksternal maupun yang berasal dari internal Kanwil DJKN itu sendiri. Adapun kendala eksternal dalam pengelolaan BMN khususnya terkait penetapan status penggunaan yaitu: 
a. dokumen persyaratan permohonan yang disampaikan tidak lengkap dan dan tidak sesuai dengan ketentuan peraturan yang terbaru, sehingga permohonan tersebut belum dapat diproses;

b. kurangnya kesadaran pimpinan satuan kerja dalam melaksanakan ketentuan di bidang Pengelolaan Barang Milik Negara khususnya pelaksanaan penetapan status penggunaan terhadap BMN yang berada dalam penguasaannya;

c. belum optimalnya fungsi pengawasan dan pengendalian Pengguna Barang terhadap pengelolaan BMN yang menjadi kewenangannya; dan

d. tidak adanya sanksi yang tegas dalam pelaksanaan ketentuan pengelolaan Barang Milik Negara.

Kendala internal yaitu:

a. kurangnya sosialisasi peraturan-peraturan di bidang pengelolaan BMN oleh Kanwil DJKN Provinsi Lampung dan Provinsi Bengkulu kepada stakeholder yang ada di Provinsi Lampung dan Provinsi Bengkulu;

b. belum didukungnya pengelolaan BMN dengan sarana dan prasarana yang handal, antara lain jumlah dan spesifikasi komputer kurang memadai, jaringan internet yang lambat dan aplikasi yang masih banyak error; dan

c. belum optimalnya fungsi pengawasan dan pengendalian dalam pengelolaan BMN yang dilakukan oleh Pengelola Barang.

Terbatasnya anggaran yang dialokasikan untuk kegiatan sosialisasi menjadi salah satu penyebab kurangnya kegiatan sosialisasi peraturan di bidang pengelolaan BMN oleh Kanwil DJKN Provinsi Lampung dan Provinsi Bengkulu. Upaya yang dapat dilakukan untuk mengatasi kurangnya sosialisasi dengan cara memberikan peraturan-peraturan di bidang pengelolaan BMN kepada stakeholder melalui surat dan menyisipkan materi peraturan di bidang pengelolaan BMN dalam kegiatan lain yang melibatkan stakeholder baik secara formal maupun informal. Dalam hal kekurangan sarana dan prasarana, upaya yang dilakukan adalah mengoptimalkan sarana yang sudah ada dan membuat surat kepada kantor pusat DJKN meminta tambahan sarana dan prasarana. Untuk mengoptimalkan fungsi pengawasan dan pengendalian oleh Pengelola Barang dapat dilakukan dengan memberikan pelatihan bagi pegawai melalui pengiriman pegawai mengikuti diklat.

\section{Penutup}

1. Simpulan

Penetapan status penggunaan Barang Milik Negara merupakan tahapan penting dalam pengelolaan BMN. Dengan ditetapkannya keputusan penetapan status penggunaan BMN, maka Pengguna Barang dan Kuasa Pengguna Barang mendapatkan penguasaan dalam penggunaan BMN untuk menyelenggarakan tugas dan fungsinya sebagai instansi pemerintah sehingga 
BMN yang diperoleh atas beban APBN atau perolehan lainnya yang sah dapat digunakan secara optimal untuk melaksanakan tugas dan fungsi Kementerian/Lembaga. Secara umum ketentuan penetapan status penggunaan BMN tidak terjadi disharmoni regulasi dan telah memenuhi ketentuan Undang-undang Nomor 12 Tahun 2011 tentang Pembentukan Peraturan Perundang-undangan yaitu pada prinsipnya peraturan perundangundangan yang lebih rendah tingkatannya tidak boleh bertentangan dengan peraturan yang lebih tinggi tingkatannya (lex superiori derogate inferioeri). Adapun secara teknis regulasi penetapan status penggunaan BMN diatur dalam Peraturan Menteri Keuangan Nomor 246/PMK.06/2014 tentang Tata Cara Pelaksanaan Penggunaan BMN dan Peraturan Menteri Keuangan Nomor 4/PMK.06/2015 tentang Pendelegasian Kewenangan dan Tanggung Jawab Tertentu Dari Pengelola Barang Kepada Pengguna Barang. Namun demikian beberapa ketentuan dalam peraturan Menteri Keuangan tersebut perlu dilakukan sinkronisasi dan harmonisasi peraturan agar tidak menimbulkan multitafsir dalam pelaksanaannya.

Kanwil DJKN Provinsi Lampung dan Provinsi Bengkulu selaku instansi vertikal Direktorat Jenderal Kekayaan Negara yang membawahi 3 (tiga) kantor pelayanan yaitu KPKNL Kota Bandar Lampung, KPKNL Kota Metro dan KPKNL Provinsi Bengkulu, telah melaksanakan salah satu fungsinya dalam mengelola kekayaan negara yaitu melakukan utilisasi kekayaan negara melalui penetapan status penggunaan BMN, namun hasil yang dicapai belum optimal karena berdasarkan data sampai dengan Tahun 2014, dari nilai aset yang dikelola di Provinsi Lampung dan Provinsi Bengkulu sebesar Rp37,1 triliun rupiah, nilai aset yang diutilisasi antara lain melalui penetapan status penggunaan Barang Milik Negara hanya sebesar Rp887,12 miliar. Penggunaan aplikasi SIMAN diharapkan dapat mendukung pengelolaan BMN khususnya pelaksanaan pengawasan dan pengendalian dalam penetapan status penggunaan BMN. Optimalisasi BMN melalui pemanfaatan bukan merupakan tujuan utama dalam pengelolaan BMN, tetapi penggunaan BMN yang optimal dalam rangka mendukung penyelenggaraan tugas dan fungsi Kementerian/Lembaga yang lebih diutamakan. Berdasarkan data Kanwil DJKN Provinsi Lampung dan Provinsi Bengkulu, dalam kurun waktu Tahun 2014 sampai dengan Tahun 2015, penerimaan negara berupa PNBP dari pengelolaan BMN melalui pemanfaatan dan pemindahtanganan BMN sebesar Rp5.053.281.841,00 (Lima Miliar Lima Puluh Tiga Juta Dua Ratus Delapan Puluh Satu Ribu Delapan Ratus Empat Puluh Satu Rupiah).

\section{Saran}

a. Kementerian Keuangan selaku regulator perlu melakukan sinkronisasi dan harmonisasi peraturan antara Peraturan Menteri Keuangan Nomor 
246/PMK.06/2014 tentang Tata Cara Pelaksanaan Penggunaan Barang Milik Negara dengan Peraturan Menteri Keuangan Nomor 4/PMK.06/2015 tentang Pendelegasian Kewenangan dan Tanggung Jawab Tertentu Dari Pengelola Barang kepada Pengguna Barang agar tidak menimbulkan perbedaan persepsi Kementerian/Lembaga dalam pelaksanaannya.

b. Kanwil DJKN Provinsi Lampung dan Provinsi Bengkulu selaku instansi vertikal Direktorat Jenderal Kekayaan Negara, agar lebih meningkatkan peranannya di bidang pengelolaan kekayaan negara melalui peningkatan fungsi pengawasan dan pengendalian dalam pengelolaan BMN dan lebih instensif dalam memberikan sosialisasi dan bimbingan teknis kepada stakeholder di Provinsi Lampung dan Provinsi Bengkulu sehingga dapat meningkatkan pemahaman dan kesadaran bagi satuan kerja dalam mengelola aset negara.

\section{Daftar Pustaka}

\section{A. Literatur}

Media Kekayaan Negara. Public-Private Partnership, Edisi No. 17 Tahun $\mathrm{V} / 2014$.

Media Kekayan Negara. Roadmap Strategic Assets Management, Edisi No. 09 Tahun III/2012.

\section{B. Peraturan Perundang-Undangan}

Undang-Undang Nomor 17 Tahun 2003 tentang Keuangan Negara.

Undang-Undang Nomor 1 Tahun 2004 tentang Perbendaharaan Negara.

Undang-Undang Nomor 12 Tahun 2011 tentang Pembentukan Peraturan Perundang-undangan.

Peraturan Pemerintah Nomor 6 Tahun 2006 tentang Pengelolaan Barang Milik Negara/Daerah.

Peraturan Pemerintah Nomor 27 Tahun 2014 tentang Pengelolaan Barang Milik Negara/Daerah.

Peraturan Menteri Keuangan Nomor 170/PMK.012012 tentang Organisasi dan Tata Kerja Instansi Vertikal Direktorat Jenderal Kekayaan Negara

Peraturan Menteri Keuangan Nomor 246/PMK.06/2014 tentang Tata Cara

Pelaksanaan Penggunaan Barang Milik Negara.

Peraturan Menteri Keuangan Nomor 4/PMK.06/2015 tentang Pendelegasian Kewenangan dan Tanggung Jawab Tertentu dari Pengelola Barang kepada Pengguna Barang.

Keputusan Menteri Keuangan Nomor 218/KM.6/2013 Tentang Pelimpahan Sebagian Wewenang Menteri Keuangan Yang Telah Dilimpahkan 
Kepada Direktur Jenderal Kekayaan Negara Kepada Pejabat di Lingkungan Direktorat Jenderal Kekayaan Negara Untuk Dan Atas Nama Menteri Keuangan Menandatangani Surat Dan/Atau Keputusan Menteri Keuangan. 